$\begin{array}{ll}\text { Volume } & : 7 \\ \text { Nomor } & : 3 \\ \text { Bulan } & : \text { Agustus } \\ \text { Tahun } & : 2021\end{array}$

\title{
Model Evaluasi CIPP dalam Mengevaluasi Program Tahfiz Selama Daring di SMP Islam Al-Ishlah Bukittinggi
}

\author{
Risdoyok \\ Institut Agama Islam Negeri (IAIN) Bukittinggi \\ Pos-el: risdoyokjournals@gmail.com
}

DOI: 10.32884/ideas.v7i3.429

\begin{abstract}
Abstrak
Program tahfihz di SMP Islam Al-Ishlah Bukittinggi selama daring (online) mengalami perubahan yang sangat signifikan, mulai dari kesiapan lembaga, guru, siswa, fasilitas, terutama pada saat pelaksanaan proses pembelajaran daring (online) berbagai kendala dihadapi. Tujuan penelitian ini untuk mengetahui implementasi program tahfiz selama proses pembelajaran daring (online). Metode penelitian menggunakan pendekatan kualitatif dengan model evaluasi CIPP (context, input, process, dan product). Hasil dari penelitian ini menunjukkan bahwa evaluasi konteks sudah baik, evaluasi masukan bisa dikatakan baik, evaluasi proses mengalami hambatan yang cukup mengkhawatirkan proses kelangsungan program tahfiz diakibatkan pandemi Covid-19 ini sehingga sangat berdampak pada proses pembelajaran tahfiz, dan evaluasi produk menunjukkan tingkat keberhasilan jauh dari apa yang telah direncanakan. Maka bisa dikatakan bahwa keberhasilan program tahfiz di masa pandemi Covid-19 mengalami kemunduran atau target yang diharapkan tidak tercapai.
\end{abstract}

\section{Kata Kunci}

model CIPP, program tahfiz, pembelajaran daring

\section{Abstract}

The tahfihz program at Al-Ishlah Islamic Junior High School Bukittinggi while online underwent very significant changes starting from the readiness of institutions, teachers, students, facilities, especially during the implementation of the online learning process, various obstacles were encountered. The aim is to find out how the tahfiz program is implemented during the online learning process. This research method uses a qualitative approach with the CIPP evaluation model (context, input, process, and product). The results of this study indicate that the context evaluation is good, the evaluation of the input can be said to be good, the evaluation of the process experienced obstacles that were quite worrying for the continuity of the tahfiz program due to the Covid-19 pandemic so that it greatly affected the tahfiz learning process, and the product evaluation showed a success rate far from what had been planned. So, it can be said that the success of the tahfiz program during the Covid-19 pandemic experienced a setback or the expected target was not achieved.

Keywords

CIPP model; tahfiz program

\section{Pendahuluan}

Membelajarkan siswa menggunakan asas pendidikan maupun teori belajar merupakan penentu utama keberhasilan pendidikan. Pembelajaran merupakan proses komunikasi dua arah, mengajar dilakukan oleh pihak guru sebagai pendidik, sedangkan belajar dilakukan oleh peserta didik atau murid. Proses pembelajaran aktivitasnya dalam bentuk interaksi belajar mengajar dalam suasana interaksi edukatif, yaitu interaksi yang sadar akan tujuan. Artinya, interaksi yang telah dicanangkan untuk suatu tujuan tertentu setidaknya adalah mencapai tujuan instruksional atau tujuan pembelajaran yang telah dirumuskan pada satuan pelajaran. Adapun pembelajaran menurut Oemar Hamalik adalah suatu kombinasi yang tersusun meliputi unsur-unsur manusiawi, material, fasilitas, pelengkapan, dan prosedur yang saling memengaruhi mencapai tujuan pembelajaran. Manusia terlibat dalam sistem pengajaran terdiri dari siswa, guru, dan tenaga lainya, misalnya tenaga laboratorium (Hamalik, 2013, p. 57)

Kegiatan pembelajaran yang diprogramkan guru merupakan kegiatan integralistik antara pendidik dengan peserta didik. Kegiatan pembelajaran secara metodologis berakar dari pihak pendidik, yaitu guru dan kegiatan belajar secara pedagogis terjadi pada diri peserta didik. Proses pembelajaran bisa disebut interaksi edukatif yang

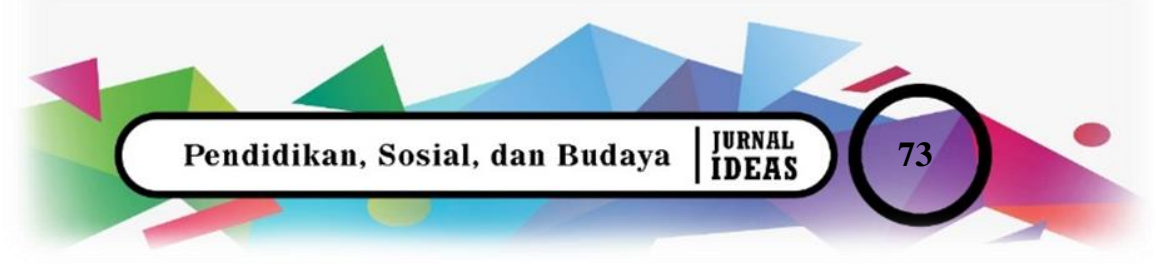




\section{ZF E-ISSH: 2656-940X P) P-ISSH: 2442-367K} URL: jurnal.ideaspublishing.co.id
Volume : 7

Nomor : 3

Bulan : Agustus

Tahun : 2021

sadar akan tujuan, artinya interaksi yang telah dicanangkan untuk suatu tujuan tertentu, setidaknya adalah tercapainya tujuan instruksional atau tujuan pembelajaran yang dirumuskan dalam satuan pelajaran. Proses pembentukan setiap rencana latihan maupun pembelajaran yang baik mulai dengan penentuan tujuan pelajaran yang tepat. Hal ini berlangsung dengan mengidentifikasi setiap mata pelajaran pokok atau topik yang harus dicakup untuk mencapai tujuan ini, kemudian pokok-pokok ini harus disesuaikan yang satu dengan yang lain untuk membentuk pelajaran itu.

Perencanaan pengajaran merupakan suatu program mengajarkan apa-apa yang sudah dirumuskan dalam kurikulum. Acuan utama penyusunan perencanaan program pengajaran adalah kurikulum. Proses pembelajaran tahfizul Alquran sangat membutuhkan perencanaan yang jitu mengingat hanya tiga jenjang waktu yang diberikan dalam menghafal Alquran. Sehubungan dengan waktu yang ditetapkan dan kemampuan guru sebagai pengelola selalu terbatas, maka para tenaga pengajar sedapat mungkin mengkonsentrasikan terhadap pelaksanaan pekerjaan dengan menjadikan peranannya yang unik dalam pengorganisasian sebagai pengelola sumber belajar. Dengan demikian, memungkinkan untuk mengisolasikan dan mengidentifikasikan empat fungsi umum yang merupakan ciri pekerjaan tenaga pengajar, di antaranya: (1) merencanakan, ini untuk menyusun tujuan belajar sesuai dengan tujuan sekolah yang terdapat dalam visi misi; (2) mengorganisasikan, ini untuk mengatur dan menghubungkan sumber-sumber belajar sehingga dapat mewujudkan tujuan belajar dengan cara yang lebih efektif, efesien, dan ekonomis; (3) memimpin, ini untuk motivator dan menstimulasi murid-muridnya sehingga dapat mewujudkan tujuan belajar; (4) mengawasi, ini untuk menentukan apakah fungsinya dalam mengorganisasikan dan memimpin untuk mewujudkan tujuan yang telah dirumuskan.

Mulyasa menyebutkan bahwa pembelajaran hakikatnya interaksi antara peserta didik dengan lingkungan sekitar sehingga terjadi perubahan prilaku ke arah yang lebih baik. Dalam pembelajaran tersebut banyak sekali faktor-faktor yang memengaruhinya. Mulai dari faktor internal yang datang dari individu, maupun faktor eksternal yang datang dari lingkungan individu tersebut (Mulyasa, 2004, p. 100).

Dalam Pendidikan Islam yang termasuk di dalamnya pembelajaran Tahfizul Alquran mempunyai tujuan yang luas dan dalam yang sangat berpengaruh pada kebutuhan hidup manusia sebagai makhluk individu dan sebagai makhluk sosial yang menghamba kepada khaliknya dengan dijiwai oleh nilai-nilai ajaran Islam. Sejalan dengan (PP. No. 55 Tahun 2007) Pasal 2 Ayat 2 menyebutkan, "Pendidikan agama bertujuan untuk berkembangnya kemampuan peserta didik dalam memahami, menghayati, dan mengamalkan nilai-nilai agama yang menyerasikan penguasaan ilmu dan teknologi dan seni”. Tujuan ini merupakan cerminan dan realisasi dari sikap penyerahan diri sepenuhnya kepada Allah Swt., baik secara perseorangan, masyarakat, maupun sebagai umat manusia keseluruhannya. Alquran merupakan pedoman pokok bagi umat Islam dalam melaksanakan ajaran-ajaran agama yang dibawa Nabi Muhammad saw., kepada umatnya. Tujuan dari Pembelajaran Tahfizul Alquran adalah membentuk insan yang memahami Alquran dan mengamalkannya dalam kehidupan sehari-hari guna menjaga keutuhan dari wahyu Ilahi (Karim, 2008, p. 19)

Selanjutnya, kegiatan yang dilakukan dalam mata pembelajaran tahfiz adalah kegiatan taqrir atau muraja'ah. Kegiatan muraja'ah adalah adalah suatu kegiatan mengulang hafalan ayat Alquran yang telah disetor kepada guru atau kepada pembimbing hafalan Alquran agar hafalannya melekat dalam hati peserta didik sehingga tidak mudah lupa. Kegiatan ini sesuai dengan sabda Nabi Muhammad saw. Dalam sebuah hadis yang berbunyi:

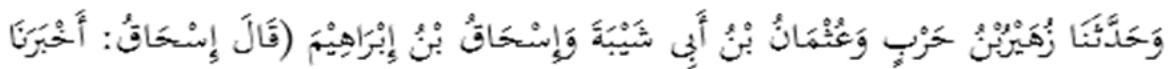

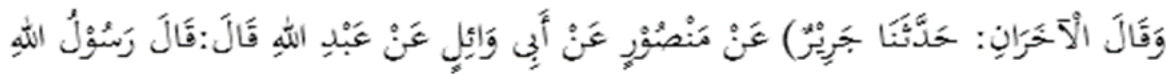

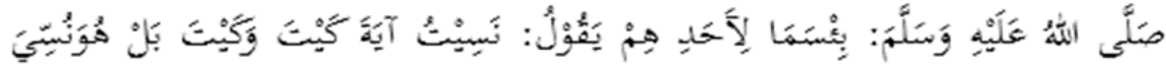

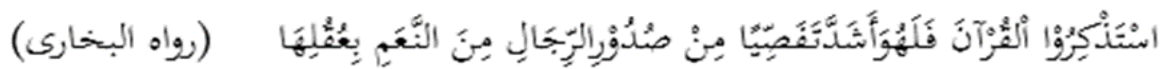

Terjemahan:

Dan telah menceritakan kepada kami Zuhairah bin Harbin dan 'Usman bin Abu Syaibah dan Ishaq bin Ibrahim (Ishaq berkata: Telah dikabarkan kepada kami dan Akharan berkata: telah menceritakan kepada kami Jarir) dari Manshub dari Abi Wail dari Abdillah dia berkata: Rasulullah sallallahu 'alaihi wa sallam bersabda, "Sangat jeleklah bagi seseorang yang mengatakan aku lupa ayat demikian dan ayat demikian, akan tetapi dia telah dibuat lupa, dan berusahalah kalian mengingat-ingat hafalan Alquran, maka sesungguhnya hafalan 
Alquran itu lebih cepat lepasnya dari dada-dada para penghafalnya, melebihi lepasnya seekor unta dari ikatannya" (HR. Bukhari).

Dari hadis di atas dapat diketahui bahwa dalam menghafal Alquran dibutuhkan kegiatan pengulangan yang berguna untuk menjaga hafalan yang telah ada sebelumnya. Jika hafalan yang telah ada itu hilang atau dilupakan oleh penghafalnya, maka hal itu merupakan suatu hal yang sangat buruk di mata Nabi Muhammad saw., dan hilangnya hafalan itu pun sangat cepat jika tidak dilakukan pengulangan. Hal ini disebabkan oleh faktor-faktor yang dapat memengaruhi hafalan tersebut hilang seperti berbuat dosa atau maksiat. Maksiat merupakan suatu hal yang kotor sehingga tidak bisa dicampur adukkan dengan Alquran yang suci (Syamsuri, 2009 , p. 155). Selain itu, dalam proses mengajar terdapat kegiatan membimbing peserta didik agar peserta didik berkembang sesuai dengan tugas-tugas perkembangannya (Sanjaya, 2011, p. 274). Kemudian memberikan latihan untuk mengembangkan keterampilan peserta didik, baik keterampilan intelektual maupun keterampilan motorik peserta didik dalam pembelajaran tahfiz. Latihan diperlukan untuk mengasah kemampuan peserta didik apalagi untuk pembelajaran yang menuntut hasil belajar berupa keterampilan atau motorik.

Dalam proses untuk ketercapain target hafalan yang sesuai dengan yang direncanakan tidak terlaksana dengan baik dikarenakan beberapa hal yang menjadi hambatannya. Sebagai contoh proses program pembelajaran tahfiz pada masa pembelajaran jarak jauh mengalami hambatan yang luar biasa, maka bisa dikatakan jauh dari kata sempurna. Sedikitnya hambatan yang ditemukan di lapangan adalah banyak dari siswa yang tidak menyetor hafalan tepat pada waktu bahkan tidak menyetor hafalannya dan berbagai alasan yang dilontarkan kepada guru tahfiz sehingga ketercapaian suatu program tersebut tidak tercapai. Hal ini terjadi karena kurangnya dorongan dan bimbingan orang tua terhadap anaknya dalam menghafal Alquran di rumah. Sejalan dengan ungkapan Sardiman bahwa dalam proses suatu program haruslah ada bimbingan dan motivasi yang kuat untuk mencapai tujuan yang direncanakan. Jika hal ini tidak ada, maka proses suatu program tersebut tidak akan berjalan dengan sempurna (Sardiman, 2004, p. 97).

Dalam proses implementasi program tentu harus ada evaluasi. Adanya evaluasi ini lebih memudahkan melihat tingkat keberhasilan dan melihat tujuan tersebut sudah tercapai atau belum. Sejalan dengan perkatakan Smith (2002) dalam jurnal Yoga menyebutkan dengan adanya evaluasi ini akan lebih mudah untuk memperbaiki hal yang belum tepat dan akan lebih mudah memotivasi siswa maupun gutu agar lebih giat agar program yang diterapkan berjalan sesaui dengan yang harapan bersama (Budi Yoga Bhakti, 2017): Model evaluasi CIPP ini sangat membantu suatu program yang sedang berlangsung dalam memberi informasi akuntabilitas dari pihak sekolah untuk mengambil tindakan yang tepat dalam memajukan program yang ada (Fuadi \& Anas, 2019). Model evaluasi CIPP yang dikembangkan oleh Stufflebeam dalam jurnal Iskandar dkk., mengatakan model evaluasi CIPP sangat baik dalam melihat sejauh mana program-program yang sedang dilaksanakan, dengan ini program tersebut bisa dilihat semua aspek yang dijalani sebelumnya (Tsani dkk., 2021) (Saepudin, 2019).

Kondisi saat ini kelanjutan program tahfiz selama wabah Covid-19 mengalami problem yang cukup mengkhawatirkan karena melihat permasalahan-permasalahan yang terjadi saat ini. Adapun model evaluasi yang tepat menurut penulis untuk mengevaluasi program tahfiz di SMP Islam Al-Ishlah adalah model CIPP (Context, Input, Process, dan Product). Titik fokus dari model CIPP ialah faktor apa yang memengaruhi keberhasilan suatu program. Santika mengatakan bahwa model evaluasi CIPP mempunyai prinsip untuk meningkatkan kualitas suatu program yang dijalankan, bukan hanya untuk membuktikan berhasil atau tidaknya program tersebut (Pramesti, 2020). Oleh karena itu, model evaluasi CIPP sangat tepat untuk meningkatkan kualitas program tahfiz di SMP Islam Al-Ishlah karena model CIPP ini bukan hanya melihat dari keberhasilan program saja akan tetapi guna meningkatkan kualitas dan kuantitas suatu program. Sejalan juga yang dikatakan endrizal bahwa model evaluasi CIPP sangat baik untuk diterapkan dalam memperbaiki dan melihat sejauh mana program yang telah dicapai, apa kendala dan apa yang harus ditinggatkan dalam program yang sedang dijalankan (Waskito, 2021).

Untuk melihat keberhasilan atau tidaknya suatu program akan lebih mudah dilihat ketika dievaluasi guna untuk melihat apakah program yang diterapkan sudah mencapai tujuan atau tidak. Kali ini peneliti menggunakan model evaluasi CIPP dalam mengevaluasi program tahfiz di SMP Islam Al-Ishlah Bukittinggi. Dengan cara ini diharapkan agar program tahfiz bisa lebih baik lagi ke depannya, terpenting untuk mengetahui sejauh mana ketercapaian program tahfiz selama pamdemi Covid-19. Diharapkan bisa menjadi tolok ukur untuk meningkatkan dan memperbaiki program tahfiz di SMP Islam Al-Ishlah.

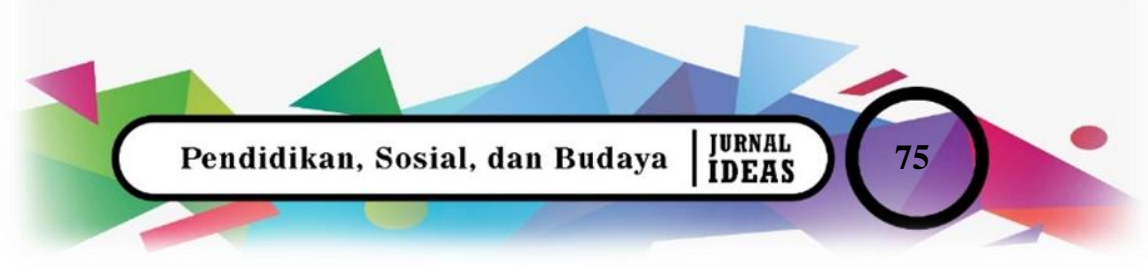




\section{Metode}

Penelitian dilaksanakan di SMP Islam Al-Ishlah Bukittinggi. Objek penelitian adalah lembaga, pendidik, serta orang tua peserta didik. Penelitian ini merupakan studi deskriptif evaluatif dengan pendekatan kualitatif. Model evaluasi yang digunakan model pendekatan evaluasi CIPP (context, input, process, dan product). Penulis menggunakan model CIPP dalam mengevaluasi program tahfiz karena sangat berkaitan dalam pengambilan keputusan "decission" yang kaitannya dengan perencanaan dalm suatu program yang diadakan (Mahmudi, 2011). Pengumpulan data menggunakan observasi dan wawancara. Tools observasi berbentuk catatan lapangan dan wawancara digunakan kepada kepala sekolah serta orang tua. Data dianalisis menggunakan model evaluasi Context, Input, Process, dan Product (CIPP).

\section{Hasil dan Pembahasan}

Hasil

Lembaga Pendidikan SMP Islam Al-Ishlah adalah salah satu lembaga Pendidikan Islam yang terletak di Kota Bukittinggi dengan lokasi yang sangat strategis. Di mana SMP Islam Al-Ishlah selain ilmu-ilmu umum peserta didik juga mendapatkan ilmu Agama penuh dari pendidik dan SMP Islam Al-Ishlah juga mempunyai program unggulan yakni tahfizqu'an. Program ini memiliki komitmen dalam mendidik peserta didik mampu menghafal Alquran dengan baik sesuai dengan kaidah-kaidah yang berlaku, di samping mengasah kemampuan dalam memiliki kompetensi akademik yang baik. Untuk hal tersebut SMP Islam Al-Ishlah telah mempersiapkan ustadzustadzah yang paham dengan Alquran serta tahfiz untuk membina peserta didik dalam program Tahfizqur'an.

Para "murabbi" (pengasuh) yang mengajarkan peserta didik dalam program tahfiz tentunya memiliki kompetensi maksimal. Hal tersebut dibuktikan ada sebahagian peserta didik yang tamat di SMP Ishlam ALIshlah hafidz, 2, 3, 4, bahkan 5 Juz Alquran. Jumlah tersebut bisa dikatakan pembuktian bahwa SMP Islam AlIshlah telah berhasil dalam menjalani program tersebut. Suksesnya program tersebut tentu tidak terlepas dari dukungan keluarga dan masyarakat yang sangat antusian dalam proses program tahfiz yang ada di SMP Islam Al-Ishlah tersebut.

Setelah mewabahnya Covid-19 di Kota Bukittinggi sejak pertengahan Maret 2020 sampai dengan sekarang yang membuat segala aktivitas pembelajaran di rumahkan. Dan berbagai upaya yang dilakukan oleh pemerintah dan lembaga-lembaga pendidikan sebisa mungkin untuk mempersiapkan proses pembelajaran dengan baik dan tak terluput pula kendala-kendala yang dihadapi dari berbagai pihak sehingga proses pembelajaran tidak berlajan dengan mulus. Hal yang serupa yang dialami oleh SMP Islam Al-Ishlah dalam mempersiapkan proses pemebalajaran selama daring (online). Singkat kata program tahfiz yang sebelumnya berjalan dengan baik dan target-target hafalan peserta didik tercapai dengan baik, sejak mewabahnya Covid-19 ini ketercapaian target sangat sulit untuk diraih oleh peserta didik karena berbagai problem yang dihadapi dalam prosesnya.

Untuk mempermudah pemahaman dalam mengevaluasi program tahfiz Quran di SMP Islam Al-Ishlah penulis uraikan secara terperinci, yakni sebagai berikut.

\section{Evaluasi Konteks (Context Evaluation)}

Context evaluation merupakan "needs assessment" analisis kebutuhan. Bahan pertanyaan dalam conteks ini adalah "apa yang dibutuhkan?" context mengadakan program tahfiz, pertanyaan yang timbul adalah "apa yang dibutuhkan anak dalam program tahfiz?" Context evaluation kali ini untuk mengetahui sejauh mana ketercapain program tahfiz di SMP Islam Al-Ishlah Bukittinggi sehingga dengan pertanyaan ini dengan mudah melihat kelemahan dan kekuatan yang dimiliki dalam program yang diterapkan serta tindakan yang hendak dilakukan (Redy \& Jaya, Partus. Ndeot, 2018)

Berdasarkan hasil wawancara (Tgl 24 Maret 2020) dengan ibu Busyra, kepala sekolah SMP Islam Al-Ishlah Bukittinggi mengatakan bahwa salah satu program ungulan di sekolah ini adalah program tahfiz Alquran, selain dikatakan daya tarik dari sekolah ini. Kami dari pihak sekolah mempunyai tekat bahwa setelah peserta didik selesai menempuh pendidikan di SMP Islam Al-Ishlah Bukittinggi ini minimal peserta didik wajib membawa hafalan tiga juz Alquran. Maka kami dari pihak sekolah selalu berupaya membimbing, mendidik, mengajarkan kepada peserta didik program tahfiz ini dengan segala upaya.

Agar program ini mempunyai dampak positif bagi siswa. Secara rinci kegiatan itu dimulai dari kegiatan memberikan motivasi dan pengarahan, kegiatan membaca, menghafal, menyetor, hingga mengulang hafalan (taqrir/muraja'ah). Dengan waktu 4 x 40 menit ini waktu normal. Selama pandemik Covid-19 ini waktu untuk 


$\begin{array}{ll}\text { Volume } & : 7 \\ \text { Nomor } & : 3 \\ \text { Bulan } & : \text { Agustus } \\ \text { Tahun } & : 2021\end{array}$

program tahfiz tidak sebanyak yang sebelumnya, yakni 2 x 30 menit. Dengan waktu yang sedikit ini cukup banyak problematika yang terjadi di saat prosesnya. Orang tua pun demikian hanya mengontrol hafalan anaknya dengan cara menannyakan saja, tapi tidak di membimbing anaknya untuk muraja'ah hafalannya bahkan ada sebagian orang tua tidak pernah mengontrol kelangsungan hafalan anak-anaknya selama di rumah sehingga guru tahfiz merasa kualahan dalam memaksimalkan hafalan siswanya ketika virtual berlangsung. Cara lain yang digunakan oleh guru tahfiz adalah memberikan target hafalan setiap minggunya dengan cara ini agar mudah mencapai apa yang direncanakan sebelumnya.

\section{Evaluasi Masukan (Input Evaluation)}

Input evaluation fakusnya pada perencanaan serta strategi apa yang diterapkan. Pertanyaan yang timbul adalah "what should be done"? Perencanaan apa saja yang harus dikerjakan oleh SMP Islam Al-Ishlah Bukittinggi terkait dengan program tahfiz? Bagaimana bentuk kerja sama pihak sekolah dengan orang tua? Bagaimana strategi pihak sekolah agar program tahfiz dapat berjalan maksimal? Apakah sarana dan prasarana mendukung dalam program tahfiz? Lalu apakah pembiayaan juga berpengaruh dalam program tahfiz? Pertanyaan ini semua akan dikembangkan secara terperinci oleh evaluator.

Berdasarkan hasil wawancara (24 Maret 2020) dengan kepala sekolah bernama Ibu Busyra menyebutkan program tahfiz dirancang secara baik dan yang berperan dalam perancangan program tahfiz pertama pihak sekolah dan dibantu oleh guru-guru tahfiz, seperti perancangan silabus, RPP, teknis pelaksanaan, teknis penilaian. Hal tersebut dilakukan secara besama-sama.

Adapun bentuk kerja sama antara orang tua dan guru dalam proses pembelajaran tahfiz selama Pandemik Covid-19, segala upaya yang dilakukan oleh pihak sekolah agar program tahizh berjalan dengan dalam situasi saat ini. Karena sama-sama kita ketahui bahwa situasi saat ini sangat berdampak pada proses pembelajaran tahfiz. Para guru tahfiz kesulitan dalam mengontrol, membimbing siswa dalam menghafal tahfzihnya. Sejalan dengan yang dikatakan oleh guru tahfiz bernama Zatul Fadhillah (24 Maret 2020) menyebutkan dalam pembelajaran tahfiz sedikitnya ada beberapa yang sangat perlu ada seperti motivasi, pengarahan, menghafal, menyetor, dan muraja'ah hafalan secara bergiliran di akhir proses pembelajaran.

Dengan adanya Pandemik Covid-19 ini proses pembelajaran tahfiz berdampak buruk karena bisa dilihat dari keseriusan, target hafalan setiap pertemuan, kedisiplinan siswa jauh dari yang diharapkan semua mengalami kemunduran sehingga bisa dikatakan program tahfiz khususnya di SMP Islam Al-Ishlah mengalami hambatan yang signifikan. Hambatan ini terjadi dikarenakan kurangnya bimbingan dan kontrol orang tua untuk membimbing anak-anaknya dalam menghafal dan muraja'ah hafalan selama di rumah. Berbagai alasan dan kendala pula yang dihadapi oleh orang tua dalam membimbing anak-anaknya selama di rumah.

Sarana dalam program tahfiz dari pihak sekolah menyediakan semua fasilitas yang berhubungan dengan tahfiz seperti Alquran khusus tahfiz, guru yang kompeten di bidang tahfiz, ruang kelas yang nyaman hal ini adalah fasilitas yang ada di sekolah. Pada situasi saat ini, di mana siswa diharuskan belajar dari rumah yang berkaitan dengan fasilitas, orang tualah yang berperan dalam memfasilitasi anak-anaknya selama belajar dari rumah. Pembiayaan khusus dalam program tahfiz tidak ada karena program tersebut sudah termasuk dari biaya sekolah anak-anak selama di SMP Islam Al-Ishlah.

\section{Evaluasi Proses (Process Evaluation)}

Pelaksanaan program dinamakan "process evaluation". Pertanyaan yang timbul adalah "it is being done?" Program tahfiz di SMP Islam Al-Ishlah Bukittingi sudah diterapkan seperti membimbing, mengarahkan, mengajarkan, membacakan, menghafalkan, menyetor serta mengulang-ulang (muraja'ah) hafalan yang telah dihafal tersebut.

Objek dari "process evaluation" adalah memastikan pelaksanaan program tahfiz apakah berjalan dengan baik ataukah tidak dengan indicator yang ada. Berdasarkan hasil wawancara dengan kepala sekolah menjelaskan bahwa selama pembelajaran dialihkan kerumah semua system yang telah direncanakan tidak belajan dengan baik karena perencanaan yang ada seperti memberi bimbingan kepada siswa yang kurang fasih atau lainnya sangat sulit karena selama pandemik Covid-19 ini kami hanya mengandalkan komunikasi internet saja, seperti Office 365 dan video call Whatsapp Groups secara bergiliran dalam waktu 2 × 30 menit dengan jumlah siswa 15 orang 1 orang guru tahfiz sehingga ketercapaian program tahfiz tersebut belum bisa dikatakan maksimal. Ditambah lagi berbagai kendala yang dihadapi pada saat virtual, seperti sinyal internet, kebosanan, dan kejenuhan siswa dalam menghafal, dan lain-lain. Hal ini sangat berpengaruh pada ketercapaian program tersebut.

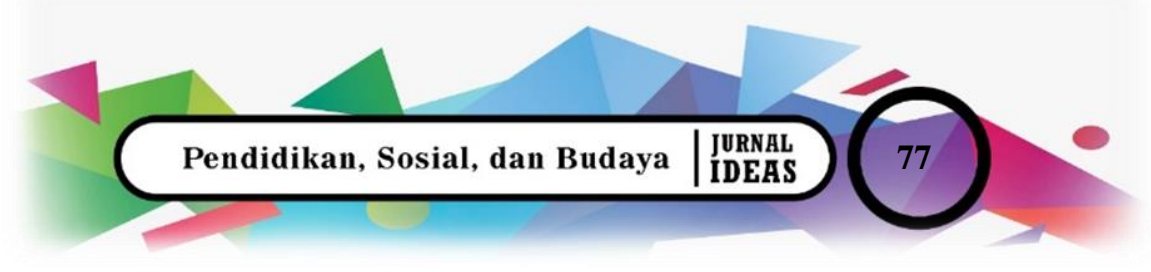


Maka dapat disumpulkan "process evaluation" program tahfiz di SMP Islam Al-Ishlah Bukittinggi mengalami hambatan yang cukup banyak. Hal ini bisa dilihat dari ketercapaian target hafalan siswa yang berkurang. Yang seharusnya hafalan siswa selama satu semester sebanyak satu juz dengan adanya hambatan ini program tahfiz pada semester ganjil ini tidak tercapai hanya separuhnya saja dan itu pun tidak semua siswa, hanya sebagian saja. Hal ini terbukti ketika penulis mewawancarai guru tahfiz bernama Joni Indra (26 Maret 2020) menyebutkan sulit untuk mencapai satu juz karena kurungnya waktu pembelajaran tahfiz dan ditambah lagi berbagai permasalahan selama proses pembelajaran daring (online) berlangsung.

\section{Evaluasi Produk (Product Evaluation)}

Terakhir adalah komponen product evaluation. Pertanyaan timbul "did it success?" Apakah program tahfiz di SMP Islam Al-Ishlah Bukittinggi berhasil? Atau sebaliknya? Pertanyaan ini menjadi focus kajian di product evaluation.

Berdasarkan hasil wawancara dengan kepala sekolah dan guru tahfiz menyebutkan tingkat keberhasilan program tahfiz selama pandemik Covid-19 ini mengalami kemunduran. Hal ini bisa dilihat dari ketidak capaian target yang telah direncanakan di awal program ini dilaksanakan, seperti target satu semester untuk siswa kelas VII surah Al-Baqarah ayat 1-120, kelas VIII surah Al-Baqarah ayat 121-220, kelas IX Surah Al-Baqarah ayat 221, Ali-Imran ayat 21 ini untuk satu semester. Akan tetapi, target ini tidak tercapai sama sekali, hanya setengah saja yang tercapai.

Sehingga program tahfiz di SMP Islam Al-Ishlah mengalami kemunduran karena berbagai faktor yang memengaruhinya seperti kurangnya peranan orang tua dalam membiming anak-anaknya selama belajar di rumah, siswa mengalami kejenuhan, kebosanan, dan yang lebih memperhantinkan lagi siswa sudah keasikkan menikmati fasilitas yang diberikan oleh orang tuanya untuk bermain sosmed ketimbang menghafal dan muraja'ah hafalan yang diberikan oleh guru.

Hal ini terjadi tidak terlepas dari kurangnya kesadaran orang tua dalam membimbing anak-anaknya dalam belajar. Sejatinya orang tualah pendidik utama bagi anaknya. Tapi hal tersebut belum juga menyadari para orang tua, pada saat ini sebahagian yang sadar akan ini. Karena hal tersebut terbukti bahwa selama belajar di rumah siswa kurang dikontrol dan ketercapaian dalam hasil belajar siswa menurun. Beberapa orang tua menyampaikan keluhan kepada pihak sekolah mulai dari fasilitas internet yang sulit, waktu kami (orang tua) yang tidak banyak untuk membimbing anak-anak kami di rumah, dan anak-anak kami lebih patuh kepada guru ketimbang kami pada saat belajar, ini yang kami alami selama pembelajaran di rumah.

Kemudian pihak sekolah selalu berupaya untuk membimbing siswa selama belajar dan bahkan kepala sekolah menintruksikan kepada para guru tahfiz agar meluangkan waktunya bagi siswa yang meminta bimbingan di waktu lain seperti selesai sekolah dengan demikian setidaknya siswa bisa memaksimalkan hafalan dan kefasihan hafalannya.

Dari hasil paparan di atas dapat disimpulkan bahwa keberhasilan dalam program tidak tercapai dengan maksimal, dikarenakan berbagai hambatan yang terjadi dalam kelangsungan prosesnya. Pembahasan merupakan bagian terpenting dari keseluruhan isi artikel ilmiah. Tujuan pembahasan adalah menjawab masalah penelitian, menafsirkan temuan-temuan, mengintegrasikan temuan dari penelitian ke dalam kumpulan pengetahuan yang telah ada dan menyusun teori baru atau memodifikasi teori yang sudah ada.

\section{Pembahasan}

Pertama kali model evaluasi CIPP (Context, Input, Process, dan Product) di kenalkan oleh Daniel Stuffleabem dkk (1967) di Ohio State University. Mula-mula model CIPP (Context, Input, Process, dan Product), digunakan untuk mengevaluasi ESEA (the Elementary and Secondary Education Act) (Arikunto; Jabar, 2014) (Djuanda, 2019) Menurut Daniel komponen dari model CIPP adalah:

"Context: "Establishing needs and objectives". Menurutnya evaluasi konteks berfokus pada intuisi yang mengidentifikasi peluang dan menialai kebutuhan; Input: "Specifying tyhe most appropriate approach to meet identified needs". Evaluasi masukan menitikberatkan pada menentukan alternatif pendekatan yang tepat guna memenuhi kebutuhan yang teridentifikasi; Process: "Assessing the implementation of the proggramme". Evaluasi proses berkaitan dengan penilaian pelaksanaan program; Product: "Assessing the outcomes of the programme". Evaluasi Produk berkaitan dengan penilaian hasil berjalannya program" (Arikunto; Jabar, 2014).

Model ini bukan hanya memfokuskan ke aspek (hasil) saja, melainkan terdapat empat aspek yang akan di evalausi. Objek model CIPP bukan hanya fokus kepada hasil saja, melainkan mencakup konteks, masukan, 


$\begin{array}{ll}\text { Volume } & : 7 \\ \text { Nomor } & : 3 \\ \text { Bulan } & : \text { Agustus } \\ \text { Tahun } & : 2021\end{array}$

proses, dan hasil.(Christiani, 2018) Oleh karena itu, model ini cukup tepat untuk mengevaluasi program tahfiz yang diterapkan oleh SMP Ishlam Al-Ishlah saat ini.

\section{Context Evaluation}

Evaluasi konteks memfokuskan menilai suatu sutuasi yang sedang dilaksanakan dalam suatu lembaga pendidikan terutama yang berkaitan dengan kekuatan dan kelemahan yang dimiliki oleh objek evalausi. Maka tugas utama evaluasi konteks adalah melakukan needs assessment serta memberikan pertimbangan terhadap program yang dilakukan (Sangadji, 2014). Tujuan evaluasi konteks adalah menilai seluruh keadaan yang terjadi dalam program, mengidentifikasi kelemahannya, menginventarisasi kekuatannya yang mampu menutupi kelemahannya, mendiagnasi problem-problem yang dihadapi oleh program, serta mencari solusi-solusi yang tepat untuk menyelesaikan problem yang dialami. Di samping itu, evaluasi konteks juga bertujuan menilai apakah tujuan dan prioritas yang telah ditetapkan memenuhi kebutuhan (Mahmudi, 2011).

Evaluasi konteks merupakan analisa kebutuhan "needs assessment". Pertama kali yang perlu diketahui “apa yang dibutuhkan?” Program tahfiz, timbul pertanyaan baru "apa yang diperlukan peserta didik dalam program tahfiz?" konteks evaluasi nya sejauh amankah ketercapain program tahfiz. Dengan adanya pertanyaanpertanyaan seperti ini akan mudah untuk melihat kekuatan dan kelemahan yang dimiliki oleh program yang hendak diterapkan (Zulherma, 2019). Kemudian evaluasi konteks juga berperan untuk mendata suatu masalah, substansi, serta peluang guna untuk membantu mengambil keputusan yang tepat agar mudah memetakan tujuan dari program yang hendak diterapkan (Pramesti, 2020).

Sehingga evaluasi konteks kali ini bertujuan untuk mengetahui apakah program tahfiz di SMP Islam Al-Ishlah sesuai dengan kebutuhan peserta didik saat ini. Melihat dari segi situasi sebelum pandemik program tahfiz terlaksana dengan baik. Namun, tibanya wabah Covid-19 ada banyak permasalahan yang terjadi serta cukup banyak kebutuhan-kebutuhan yang diperlukan baik pihak sekolah, guru, orang tua siswa selama prosesnya sehingga menimbulkan permasalahan baru dalam pelaksanaan program ini.

\section{Input Evaluation}

Evaluasi masukan difokuskan untuk memberikan pertimbangan terhadap keberhasilan program yang sedang dilaksanakan (Sangadji, 2014). Selain memberikan petimbangan terhadap keberhasilan suatu program segi lain juga berfungsi sebagai melaksanakan perubahan-perubahan yang mungkin dibutuhkan. Evaluasi masuk adalah mencari hambatan serta potensi sumber daya yang tersedia. Tujuan utama evaluasi input adalah membantu klien mengkaji alternatif yang berkenaan dengan kebuthuan program, serta membantu klien dalam menghindari inovasi yang sia-sia dan sekiranya akan gagal dalam membantu kebutuhan dari program tersebut (Mahmudi, 2011). Sejalan dengan jurnal yang dibuat oleh Syahrir dkk., mengatakan evaluasi input berfungsi sebagai mengidentifikasi program ekternal serta material dalm pengumpulan informasi yang terdapat pada dimensi (Syahrir dkk., 2021).

Menurut Widoyoko (2014) dalam jurnal Petrus \& Felisitas menyebutkan evaluasi imput berperan sebagai membantu dalam mengatur keputusan yang berkaitan dengan s rencana serta strategi dalam mencapai program. Fokusnya mengkaji (a) sumber daya manusia, (b) alat pendukung dan sarana, (c) pembiayaan, dan (d) berbagai prosedur/aturan sekiranya dibutuhkan (Redy \& Jaya, Partus. Ndeot, 2018).

Input evaluation fokusnya pada perencanaan serta strategi apa yang diterapkan. Pertanyaan yang timbul adalah "what should be done"? Perencanaan apa saja yang harus dikerjakan oleh SMP Islam Al-Ishlah Bukittinggi terkait dengan program tahfiz? Bagaimana bentuk kerja sama pihak sekolah dengan orang tua? Bagaimana strategi pihak sekolah agar program tahfiz dapat berjalan maksimal? Apakah sarana dan prasarana mendukung dalam program tahfiz? Lalu apakah pembiayaan juga berpengaruh dalam program tahfiz? Pertanyaan ini semua akan dikembangkan secara terperinci oleh evaluator.

\section{Process Evaluation}

Evaluasi proses merupakan ditujukan kepada kegiatan atau realita yang berlangsung (Sangadji, 2014). Pelaksanaan program dinamakan "process evaluation". Pertanyaan yang timbul adalah "it is being done?". Program tahfiz di SMP Islam Al-Ishlah Bukittingi sudah diterapkan seperti membimbing, mengarahkan, mengajarkan, membacakan, menghafalkan, menyetor serta mengulang-ulang (muraja'ah) hafalan yang telah di haaln tersebut. Maka tujuan dari evaluasi proses merupakan memberi masukkan bagi pengelola/manejer serta stafnya tentang kesesuaian antara pelaksanaan renacan dan jadwal yang sudah dibuat sebelumnya. Kiranya rencana awal ada yang hendak dimodifikasi/dikembangkan, maka evaluasi proses memberi jalannya. Segi lain 
evaluasi proses sebagai tolak ukur keberhasilan-keberhasilan dalam pelaksanaan peran serta evaluasi proses memberikan catatan lengkap terhadap pelaksanaan rencana yang telah diperhitungkan sebelumnya (Mahmudi, 2011). Jurnal yang buat oleh Made Dike \& Madjid menyebutkan evaluasi prosesbertugas memaparkan tentang proses berlangsungnya program tahfiz tersebut, meliputi keterlibatan peserta didik, komunikasi guru dengan peserta didik, kecocokkan antara yang telah direncanakan dengan implementasikan, meteri, alat/media, metode pelaksanaan, serta sistem penilaian dalam program (Dike dkk., 2021).

\section{Product Evaluation}

Terakhir Evaluasi hasil ditujukan untuk menentukan sudah sejauh mana program yang diimplementasikan tersebut telah dapat memenuhi kebutuhan objek penelitian.(Sangadji, 2014) Pertanyaan timbul "did it success?" Apakah program tahfiz di SMP Islam Al-Ishlah Bukittinggi berhasil? Atau sebaliknya? Pertanyaan ini menjadi focus kajian di product evaluation. Bisa dikatakan evaluasi produk bertujuan untuk menafsirkan, mengukur, serta menilai ketercapaian program. Penilaian tentang suatu keberhasilan program yang dilaksanakan. Sehingga dengan hal ini akan tampak gagal ataukah berhasil dari program yang dijalani serta dianalisis dari berbagai sudut pandang (Mahmudi, 2011). Serupa yang dikatakan Santika dalam jurnalnya evaluasi produk guna mengidentifikasi serta memberi penilaian terhadap hasil yang akan dicapai dari program yang dilaksanakan, baik dari segi pelaksanaan kegiatan agar mencapai sasaran program dalam upaya memenuhi kebutuhan kelompok sasaran (Pramesti, 2020).

\section{Simpulan}

Dengan menggunakan model evaluasi CIPP proses program tahfiz di SMP Islam Al-Ishlah selama Covid-19 tampak jelas mengalami permasalahan disetiap kompomen-komponen mulai dari context, input, process, dan product sehingga keberhasilan program tahfiz di SMP Islam Al-Ishlah Bukittinggi dalam situasi wabah Covid-19 mengalami hambatan dalam mencapai target yang telah ditetapkan sebelumnya. Hal ini sebebkan berbagai factor seperti faktor internal siswa maupun faktor eksternal siswa. Faktor-faktor ini sangat berpengaruh terhadap keberhasilan dalam suatu program apalagi program tahfiz yang membutuhkan bimbingan yang cukup. Adanya wabah Covid-19 ini semua sistem yang telah direncanakan tidak berjalan sepenuhnya. Hal lain disebabkan oleh orang tua yang acuh dalam proses pembelajaran daring (online) anak sehingga berdampak terhadap keberhasilan anak dalam pembelajaran.

\section{Daftar Rujukan}

Arikunto; Jabar, S. (2014). Evaluasi Program Pendidikan. PT Bumi Aksara.

Budi Yoga Bhakti. (2017). Evaluasi Program Model CIPP Pada Proses. Jurnal Inovasi Pendidikan Fisika Dan Riset Ilmiah, $1(2), 75-82$.

Christiani, Y. (2018). Penerapan Model Cipp Dalam Evaluasi Implementasi Kurikulum 2013. 6, 1-6.

Dike, M., Ilyasa, J., \& Madjid, A. (2021). Evaluasi Program Terapi Al- Qur'an M elalui Model Context, Input, Process, Product (CIPP). 13(1).

Djuanda, I. (2019). Implementasi Evaluasi Program Pendidikan Karakter Model Cipp (Context, Input, Process Dan Output). Journal of Chemical Information and Modeling, 53(9), 1689-1699.

Fuadi, A. S., \& Anas, M. (2019). Implementasi Model CIPP dalam Evaluasi Kurikulum 2013 Pendidikan Ekonomi. Prosiding SEMDIKJAR (Seminar Nasional Pendidikan Dan Pembelajaran), 3, 316-324. http://ojs.semdikjar.fkip.unpkediri.ac.id/index.php/SEMDIKJAR/article/view/32

Hamalik, O. (2013). Kurikulum Dan Pembelajara. Bumi Aksara.

Karim, K. (2008). Mengapa Saya Menghafal Alqur'an. Daar Annaba.

Mahmudi, I. (2011). CIPP: Suatu Model Evaluasi Program Pendidikan. Jurnal At-Ta'dib, 6(1), 118

Mulyasa, E. (2004). Kurikulum Berbasis Kompetensi, Konsep, Karakteristik Dan Implementasi. Remaja Rosdakarya.

Pramesti, S. L. D. (2020). Evaluasi Pembelajaran Matematika Pada Boarding School Berdasarkan Model Cipp. Integral: Pendidikan Matematika, 11(1), 17-32. https://e-journal.umc.ac.id/index.php/JNR/article/view/1139

Redy, P., \& Jaya, Partus. Ndeot, F. (2018). Mengevaluasi Program Layanan Paud Holistik Integratif. PERNIK Jurnal PAUD, l(1), 10-25.

Saepudin, Y. N. (2019). Evaluasi Pembelajaran Pada Pelatihan Parenting Dengan Menggunakan Pendekatan Model Cipp

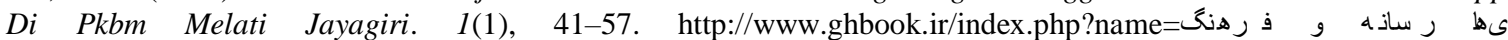

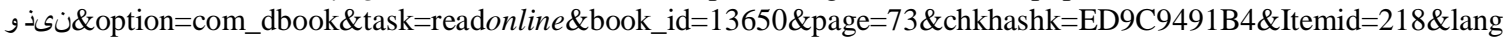
=fa\&tmpl=component\%0Ahttp://www.albayan.ae\%0Ahttps://scholar.google.co.id/scholar?hl=en\&q=APLIKASI+PEN GENA

Sangadji, K. (2014). Model Cipp Untuk Evaluasi Pengembangan Ktsp Pada Jenjang Pendidikan Persekolahan. Jurnal Biologi, 3(2), 79-87.

Sanjaya, W. (2011). Kurikulum Dan Pembelajaran. Kencana Prenada Media Group.

Sardiman. (2004). Interaksi Dan Motivasi Belajar Mangajar. Raja Grafindo Persada. 
Syahrir, Supriyati, Y., \& Fauzi, A. (2021). Evaluasi Dampak Program Pendidikan Jarak Jauh (PJJ) melalui model CIPP pada Kinerja Dosen aspek Pembelajaran pada Masa Pendemi Covid 19. Jurnal Ilmiah Mandala Education, 7(1), 144-150.

Syamsuri. (2009). Menggapai Mukjizat Alquran; Berita Surga Bagi Para Pecinta Alquran. Al-Manar.

Tsani, I., Arsyadana, A., \& Shafira, E. (2021). Evaluasi Model Cipp Pada Pembelajaran Pai Dan Budi Pekerti Di Sma Negeri 7 Kota Kediri. 12(1), 17-45.

Waskito, E. W. (2021). Evaluasi Program Pembelajaran Pemeliharaan Kelistrikan Sepeda Motor Menggunakan Model CIPP. 5, 17-26.

Zulherma, F. M. N. E. S. L. (2019). Penerapan Model Evaluasi Cipp Dalam Mengevaluasi Pembelajaran Seni Grafis Stencil Print Di Taman Kanak-Kanak. Культура Kультуры, 3(2), 1434-1439. 
글 E-ISSH: 2656-940X $\quad$ Volume : 7

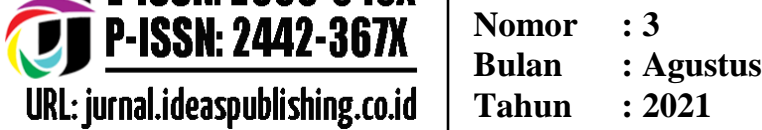

